\title{
High Expression of Truncated Viral Rep Protein Confers Resistance to Tomato Yellow Leaf Curl Virus in Transgenic Tomato Plants
}

\author{
A. Brunetti, ${ }^{1}$ M. Tavazza, ${ }^{1}$ E. Noris,${ }^{2}$ R. Tavazza, ${ }^{1}$ P. Caciagli, ${ }^{2}$ G. Ancora, ${ }^{1}$ S. Crespi, ${ }^{2}$ \\ and G. P. Accotto ${ }^{2}$ \\ ${ }^{1}$ ENEA, Dipartimento Innovazione, C.R. Casaccia, Via Anguillarese 301, 00060 S. Maria di Galeria (Roma), \\ Italy; ${ }^{2}$ Istituto di Fitovirologia Applicata, CNR, Strada delle Cacce 73, 10135 Torino, Italy \\ Received 8 November 1996. Accepted 16 April 1997.
}

\begin{abstract}
A truncated version of the $C 1$ gene of tomato yellow leaf curl geminivirus (TYLCV), encoding the first 210 amino acids of the multifunctional Rep protein, was introduced by Agrobacterium transformation into Lycopersicon esculentum cv. Moneymaker plants under the transcriptional control of an enhanced cauliflower mosaic virus $35 \mathrm{~S}$ promoter. One $R_{0}$ plant (line 47 ) carrying the $C 1$ gene in two loci ( $A$ and $B$ ) and accumulating the truncated Rep protein (T-Rep), was crossed with either a wild-type plant, or a $C 1$ antisense plant (line 10). The wild type $(w t) \times 47$ progeny were phenotypically homogeneous, contained either A or B locus, expressed high levels of T-Rep protein, had a "curled" phenotype, and were resistant to TYLCV when challenged either by agroinfection or by the vector Bemisia tabaci. In the $10 \times 47$ progeny, plants carrying only the sense gene behaved like the wt $\times 47$ progeny, while those containing both sense and antisense transgenes did not accumulate the T-Rep protein, showed a normal phenotype, and were not resistant, showing that accumulation of T-Rep protein is required to confer TYLCV resistance. Plants accumulating T-Rep were susceptible to a distinct geminivirus, tomato leaf curl virus (ToLCV-Au).
\end{abstract}

Tomato yellow leaf curl virus (TYLCV) is classified in subgroup III of the family Geminiviridae. It is transmitted by the whitefly Bemisia tabaci and causes economically important disease in tomato (Lycopersicon esculentum) in tropical and subtropical regions (Czosnek et al. 1990). TYLCV isolates from several countries have been described and are currently grouped in three species (Briddon and Markham 1995): TYLCV-Sr (Kheyr-Pour et al. 1991), TYLCV-Is (Navot et al. 1991), and TYLCV-Th (Rochester et al. 1994).

Classical breeding has been attempted to introduce TYLCV resistance to tomato cultivars, which currently are all susceptible. Although some wild relatives of tomato (L. chilense and L. peruvianum) are resistant, introduction of resistance traits into commercial tomatoes is complicated by several factors. Resistance appears to be controlled by one to five genes, either recessive or dominant (Zakay et al. 1991). Crosses have

Corresponding author: M. Tavazza

E-mail: tavazza_m@infos1.casaccia.enea.it produced only TYLCV-tolerant hybrids (Michelson et al. 1994; Zamir et al. 1994).

Recently, several strategies have been used to engineer plants resistant to viral pathogens (Lomonossoff 1995). Most are based on the concept that the introduction and expression in plants of viral sequences could interfere with the viral life cycle (Sanford and Johnston 1985). To confer resistance to geminiviruses, three approaches have been attempted with virus-derived sequences. First, genes in antisense orientation: primary transformant $\left(\mathrm{R}_{0}\right)$ tobacco plants expressing the antisense DNA sequence of the $A L 1$ gene of tomato golden mosaic virus (TGMV; Day et al. 1991) were symptomless when agroinoculated, although the presence of viral DNA was detected in most of them. Second, defective interfering (DI) DNA: Nicotiana benthamiana plants transformed with DI DNA either of African cassava mosaic virus (ACMV; Stanley et al. 1990) or beet curly top virus (BCTV; Frischmuth and Stanley 1994; Stenger 1994) showed symptom amelioration when challenged with the respective viruses. Third, wild-type genes: a delayed appearance of TYLCV-Is symptoms followed by a recovery of viral infection was described in $\mathrm{R}_{0}$ plants of an interspecific tomato hybrid transformed with the coat protein gene of TYLCV-Is (Kunik et al. 1994). Recently, Hong and Stanley (1996) reported that $N$. benthamiana plants transformed with the wild-type $A C 1$ gene of ACMV showed some resistance to ACMV infection. None of these strategies was completely satisfactory.

The use of dominant negative mutants (Herskowitz 1987) is another strategy to confer virus resistance. In geminiviruses, the replication-associated protein (Rep; Laufs et al. 1995) seems an opportune candidate. This protein, encoded by open reading frame (ORF) $C 1$ in TYLCV (also called $A L 1$ or $A C 1$ in other geminiviruses), is multifunctional and is involved in both viral replication (Hanley-Bowdoin et al. 1990; Lazarowitz et al. 1992; Fontes et al. 1992, 1994) and transcriptional regulation (Sunter et al. 1993; Eagle et al. 1994). It is the only viral protein required for replication of viral DNA (Elmer et al. 1988; Etessami et al. 1991) and it contains separate functional domains. The amino-terminal domain is involved in viral DNA recognition and binding (Jupin et al. 1995; Choi and Stenger 1995; Hong and Stanley 1995) and in the cleavage and joining of the origin of DNA replication (HeyraudNitschke et al. 1995), while the carboxy-terminal portion 
contains an nucleoside triphosphate-binding domain required for viral replication (Hanson et al. 1995; Desbiez et al. 1995).

We have recently shown (Noris et al. 1996) that the expression in $N$. benthamiana plants of a TYLCV-Sr Rep protein lacking the carboxy-terminal portion (truncated Rep, T-Rep) can efficiently interfere with TYLCV-Sr infection. In the present work, we have obtained tomato plants expressing and accumulating T-Rep. These plants were examined for resistance to TYLCV-Sr when infected by either agroinoculation or whitefly transmission. Antisense strategy was used to study the consequences of reduced transgene expression on resistance. Plants were also challenged with a distinct geminivirus, tomato leaf curl virus (ToLCV-Au).

\section{RESULTS}

\section{Molecular characterization of transformed tomato.}

Fifteen tomato plants transformed with the plasmid pTom 102 harboring the truncated $C 1$ gene under the transcriptional control of an enhanced 35S (E35S) promoter were obtained from three independent cotyledon explants. When transformants were analyzed by polymerase chain reaction (PCR) for the presence of $C 1$ and nptII transgenes, fragments of predicted size were amplified from all plants (data not shown). One plant from each original independent explant was transferred to soil and further analyzed at the molecular level. A Southern blot of genomic DNA of the three transgenic tomato plants, restricted with $K p n I$ and hybridized with a $C 1$-specific probe, is shown in Figure 1A. KpnI cuts at a single site in the T-DNA on the $5^{\prime}$ side of the E35S, releasing different DNA fragments depending on the number of integrated T-DNA copies. Two hybridizing bands were seen in KpnI-digested
DNA from plant 47 and four from plant 104, while a broad high-molecular-weight signal was detected in plant 114 (Fig. 1A). Further restriction analysis with HindIII and BamHI confirmed that plant 47 contained two copies of the $C 1$ transgene, while a more complex pattern, accounting for four or more $C 1$ copies, was detected in plants 104 and 114 (data not shown). Northern (RNA) blot analysis with an antisense C1 RNA probe revealed a $C 1$-specific mRNA of approximately 1,100 nucleotides in poly $(\mathrm{A})^{+}$-enriched RNA isolated from plants 47 and 104 but not from plant 114 (Fig. 1B). With the anti-C1 specific serum, the T-Rep protein, with apparent molecular mass of $26 \mathrm{kDa}$, was detected in Western blots (immunoblots) of total protein extracts from plant 47 but not from plants 104 and 114 (Fig. 1C).

Since previous work on $N$. benthamiana has shown the importance of $C l$ transgene expression for the resistance to TYLCV-Sr (Noris et al. 1996), plant 47, expressing the $C 1$ transgene at both mRNA and protein levels, was selected for further study. This plant had the same ploidy level as a nontransformed plant, when analyzed by flow cytometry (data not shown), and was phenotypically normal, except that the leaves were a paler green.

\section{TYLCV-Sr resistance in plants accumulating the T-Rep protein.}

Self-pollinated seed from plant 47 was harvested and analyzed. T-Rep was easily detected in all the $\mathrm{R}_{1}$ seedlings analyzed (data not shown). However, $\mathrm{R}_{1}$ plants, from seeds germinated either on agar plates or in soil, did not grow properly, showed pronounced leaf curling and wilting, and most of them died within 2 to 4 weeks of germination. It was therefore impossible to test the virus resistance of $\mathrm{R}_{1}$ progeny. Among ap-
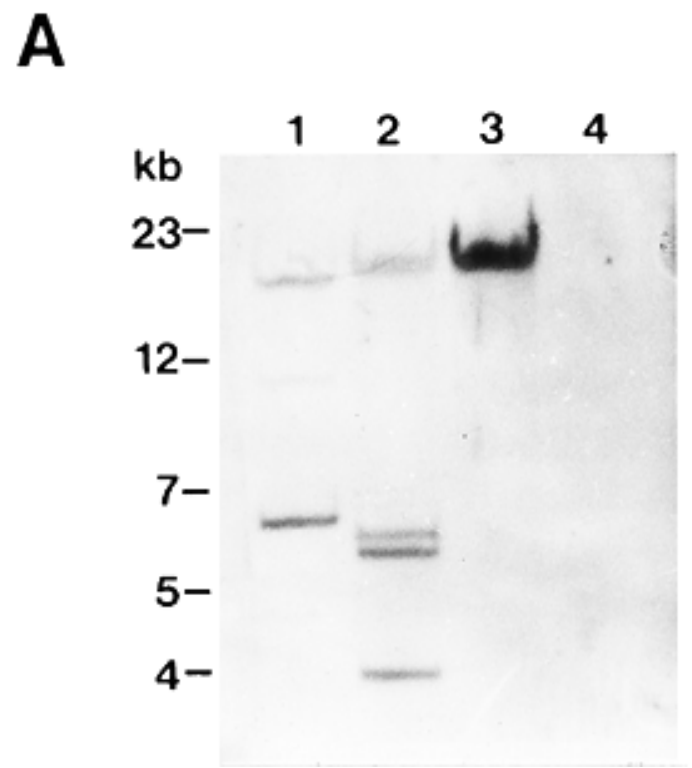

B

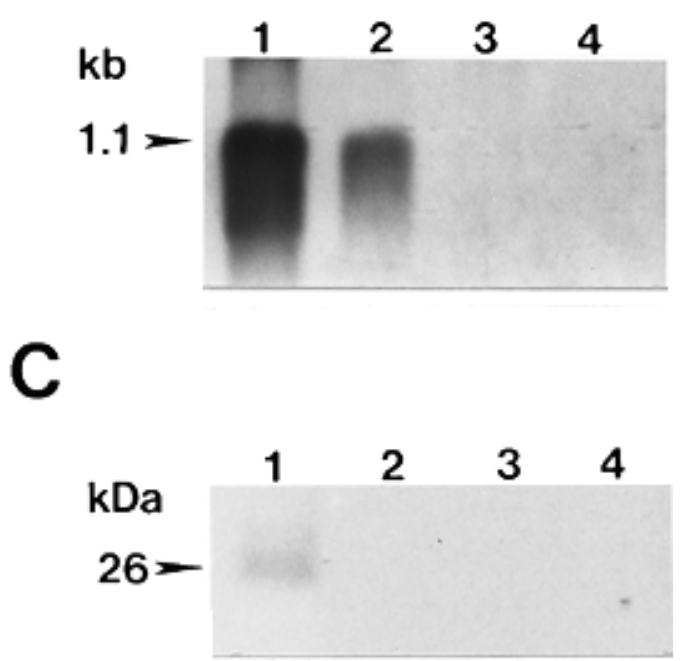

Fig. 1. Molecular analysis of primary transformant tomato plants. A, Southern blot analysis of total DNA ( $2 \mu \mathrm{g}$ ) extracted from transgenic plants 47 (lane 1), 104 (lane 2), and 114 (lane 3) and a nontransformed plant (lane 4) restricted with KpnI and hybridized with a C1 sense digoxigenin-labeled RNA probe. Positions and sizes of molecular markers are indicated. B, Northern (RNA) blot analysis of polyadenylated RNAs extracted from transgenic plants 47 (lane 1), 104 (lane 2), and 114 (lane 3) and a nontransformed plant (lane 4) fractionated on formaldehyde-permeated agarose gel and hybridized with a $C 1$ antisense digoxigenin-labeled RNA probe. Arrow shows the transcript $(1.1 \mathrm{~kb})$. C, Western blot (immunoblot) analysis of total proteins (about 500 ng/lane) extracted from the transgenic plants 47 (lane 1), 104 (lane 2), and 114 (lane 3) and nontransformed plant (lane 4) probed with Rep-specific antibodies. Arrow shows the truncated Rep protein, with a molecular mass of about $26 \mathrm{kDa}$. 
proximately $300 R_{1}$ seedlings no segregants with wild-type phenotype were observed.

To analyze the effect on resistance of protein expression driven by each $C l$ gene copy, and to overcome the "toxic" effect observed in the selfed progeny, the pollen of $R_{0}$ plant 47 was used to fertilize flowers of wild-type plants, obtaining BC1 seeds. A total of $55 \mathrm{BC} 1$ plants were analyzed. They were phenotypically homogeneous and, at the 4- to 6-leaf stage, could be distinguished from wild-type plants only by a slightly paler green color. PCR analysis showed that all of them contained the $C l$ gene.

Southern blot analysis of $27 \mathrm{BC} 1$ plants was performed. Total DNA, restricted with HindIII, which cuts in the $5^{\prime}$ untranslated region of the $C 1$ transgene construct, was hybridized with a E35S-specific probe, to generate one specific hybridizing fragment for each integrated T-DNA copy. Two hybridizing fragments of about 9 and $1.8 \mathrm{~kb}$ (referred hereafter as loci A and B, respectively) accounting for the two integrated copies, were seen in the $\mathrm{R}_{0}$ plant 47 (Fig. 2, lane 2), while in the $\mathrm{BC} 1$ progeny either the $9-\mathrm{kb}$ (13 plants) or the 1.8-kb fragment (14 plants) was present (Fig. 2, lanes 4 and 5; and data not shown). No plant was found containing both loci or none.

A total of 13 plants, 6 containing locus A and 7 locus B, were chosen for further molecular analysis and resistance assays. Molecular analysis showed that all plants expressed $\mathrm{Cl}$ specific mRNA and T-Rep protein (Fig. 3A, B and C, lanes 1 to 5; and data not shown) in similar amounts, independently of which locus was present. The intensity and sharpness of the protein band on Western blots were better than what was observed on the $\mathrm{R}_{0}$ plant 47 (compare with Fig. 1C, lane 1), even when loaded on the same gel.

These 13 plants, together with 6 wild-type plants, were agroinoculated with TYLCV-Sr and the infection was monitored for the following 18 weeks (Table 1). Four weeks post infection

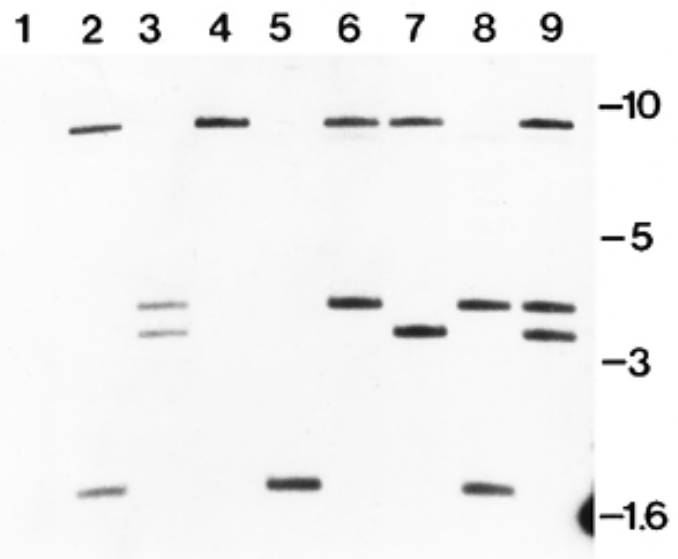

Fig. 2. Southern blot analysis of primary transformant tomato plants 47 and 10 and some selected $F_{1}$ progeny of crosses wild type $(w t) \times 47$ and $10 \times 47$. Total DNA $(2 \mu \mathrm{g})$ extracted from a nontransformed tomato plant (lane 1), and $\mathrm{R}_{0}$ transgenic plants 47 (lane 2) and 10 (lane 3), $\mathrm{BC} 1$ progeny deriving from cross $w t \times 47$, plants \#1 (lane 4) and \#2 (lane 5), and $F_{1}$ progeny deriving from cross $10 \times 47$ plants \#31 (lane 6), \#50 (lane 7), \#51 (lane 8), and \#52 (lane 9) was digested with HindIII and hybridized with an E35S digoxigenin-labeled RNA probe. Positions and sizes $(\mathrm{kb})$ of molecular markers are indicated. (wpi) TYLCV-Sr DNA could not be detected in the BC1 plants, while it was present in all control plants, which displayed typical TYLCV symptoms. During the experiment the resistant transgenic plants developed curled leaves and produced sterile flowers (Fig. 4A), thus impairing an easy detection of TYLCV
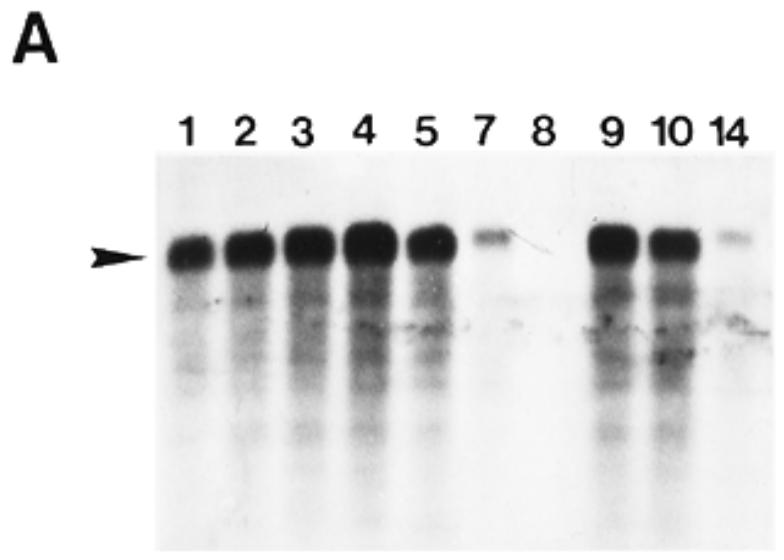

B
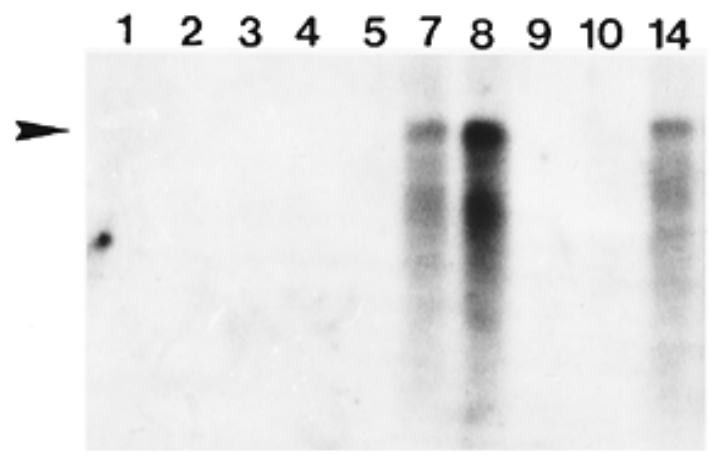

C

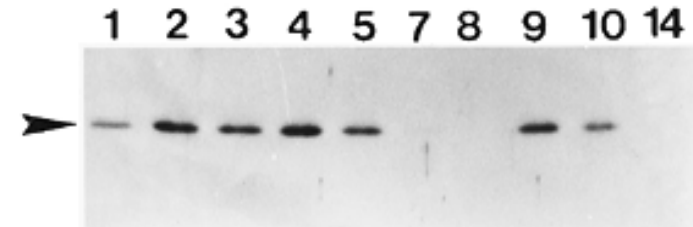

Fig. 3. Transgene expression in $\mathrm{F}_{1}$ tomato plants of crosses wild type $(w t) \times 47$ and $10 \times 47$. Samples from BC1 wt $\times 47(\# 1,2,3,4$, and 5) and $F_{1} 10 \times 47$ plants $(\# 7,8,9,10$, and 14) are shown in each panel. A, Total RNA $(20 \mu \mathrm{g})$ was analyzed in Northern (RNA) blots with a $C 1$ antisense digoxigenin-labeled RNA probe. Arrow indicates the transcript. B, Northern analysis of the total RNAs shown in A, hybridized with a $C 1$ sense digoxigenin-labeled RNA probe. C, Western (immunoblot) analysis of transgenic $\mathrm{C} 1$ protein expression with Rep-specific antibodies. Arrow indicates the $26 \mathrm{kDa}$ truncated Rep protein. 
symptoms on leaves and making necessary the use of a leafsquash assay. None of the $\mathrm{BC} 1$ plants was found infected in assays performed till $7 \mathrm{wpi}$; however, in the period from 8 wpi to the end of the experiment, 8 transgenic plants remained resistant while 5 became infected ( 3 with locus A and 2 with B). No correlation was found between the occurrence or timing of infection and the presence of a specific locus.

Resistance was further analyzed by challenging $5 \mathrm{BC} 1$ transgenic and 4 control plants with viruliferous Bemisia tabaci. All the control plants were infected at 4 wpi while none of the transgenic plants proved positive in the leaf squash assay up to the end of the experiment (16 wpi).

To further elucidate the resistance phenomenon, two independent leaf disk infection experiments were performed. In each experiment leaf disks derived from two $\mathrm{BC} 1$ plants and one control plant were agroinoculated with the TYLCV-Sr

Table 1. Results of resistance assays on $13 \mathrm{BC} 1$ (wild type $\times 47$ ) plants, with reference to the presence of $C l$ transgene in locus A or B

\begin{tabular}{lcl}
\hline Plant no. & Locus $^{\mathbf{a}}$ & Resistance $^{\mathbf{b}}$ \\
\hline 1 & $\mathrm{~A}$ & $\mathrm{R} \rightarrow \mathrm{S}(18 \mathrm{wpi})^{\mathrm{c}}$ \\
2 & $\mathrm{~B}$ & $\mathrm{R}^{\mathrm{d}}$ \\
3 & $\mathrm{~B}$ & $\mathrm{R}$ \\
4 & $\mathrm{~B}$ & $\mathrm{R} \rightarrow \mathrm{S}(9 \mathrm{wpi})$ \\
5 & $\mathrm{~B}$ & $\mathrm{R} \rightarrow \mathrm{S}(18 \mathrm{wpi})$ \\
6 & $\mathrm{~A}$ & $\mathrm{R} \rightarrow \mathrm{S}(8 \mathrm{wpi})$ \\
7 & $\mathrm{~A}$ & $\mathrm{R} \rightarrow \mathrm{S}(17 \mathrm{wpi})$ \\
8 & $\mathrm{Aom}$ & $\mathrm{R}$ \\
9 & $\mathrm{~A}$ & $\mathrm{R}$ \\
10 & $\mathrm{~A}$ & $\mathrm{R}$ \\
11 & $\mathrm{~B}$ & $\mathrm{R}$ \\
12 & $\mathrm{~B}$ & $\mathrm{R}$ \\
13 & $\mathrm{~B}$ & $\mathrm{R}$ \\
\hline
\end{tabular}

${ }^{a}$ Locus determined by Southern blot analysis.

${ }^{\mathrm{b}}$ Resistance to agroinoculation with TYLCV-Sr

${ }^{\mathrm{c}}$ Resistance lost at 18 wpi (weeks post inoculation)

${ }^{\mathrm{d}}$ Resistance maintained to the end of the experiment. infectious clone, and viral DNA replication was analyzed 6 days post infection by Southern blotting (Fig. 5). TYLCV-Sr DNA was detected in leaf disks from nontransformed plants while it was hardly or not detectable in leaf disks from BC1 plants (Fig. 5).

\section{Down-accumulation of T-Rep protein, by expression of $C 1$ antisense RNA, switches the phenotype from resistant to susceptible.}

To explore the possibility of altering the steady-state level of $C 1 \mathrm{mRNA}$ and T-Rep, and then testing virus resistance, $\mathrm{F}_{1}$ hybrid progeny were obtained by fertilizing line 10 with pollen from line 47 . Line 10 was an $\mathrm{R}_{0}$ transgenic plant carrying two copies of the truncated $C 1$ gene cloned in antisense orientation under the control of the E35S promoter (see plasmid pTom 103 described by Noris et al. [1996]). Flow cytometric analysis showed that its ploidy level was normal. Twenty $10 \times$

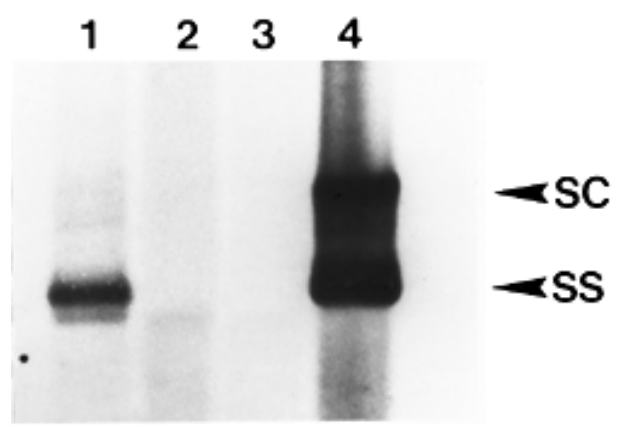

Fig. 5. Tomato yellow leaf curl virus (TYLCV) DNA replication in BC1 transgenic tomato leaf disks. Total DNA was extracted from leaf disks from a nontransformed plant (lane 1), and two BC1 plants (lanes 2 and 3) agroinoculated with a TYLCV infectious clone and from a TYLCVinfected tomato plant (lane 4). Blot was hybridized with a $C 1$ sense digoxigenin-labeled RNA probe. sc: supercoiled TYLCV dsDNA. ss: single-stranded TYLCV DNA.
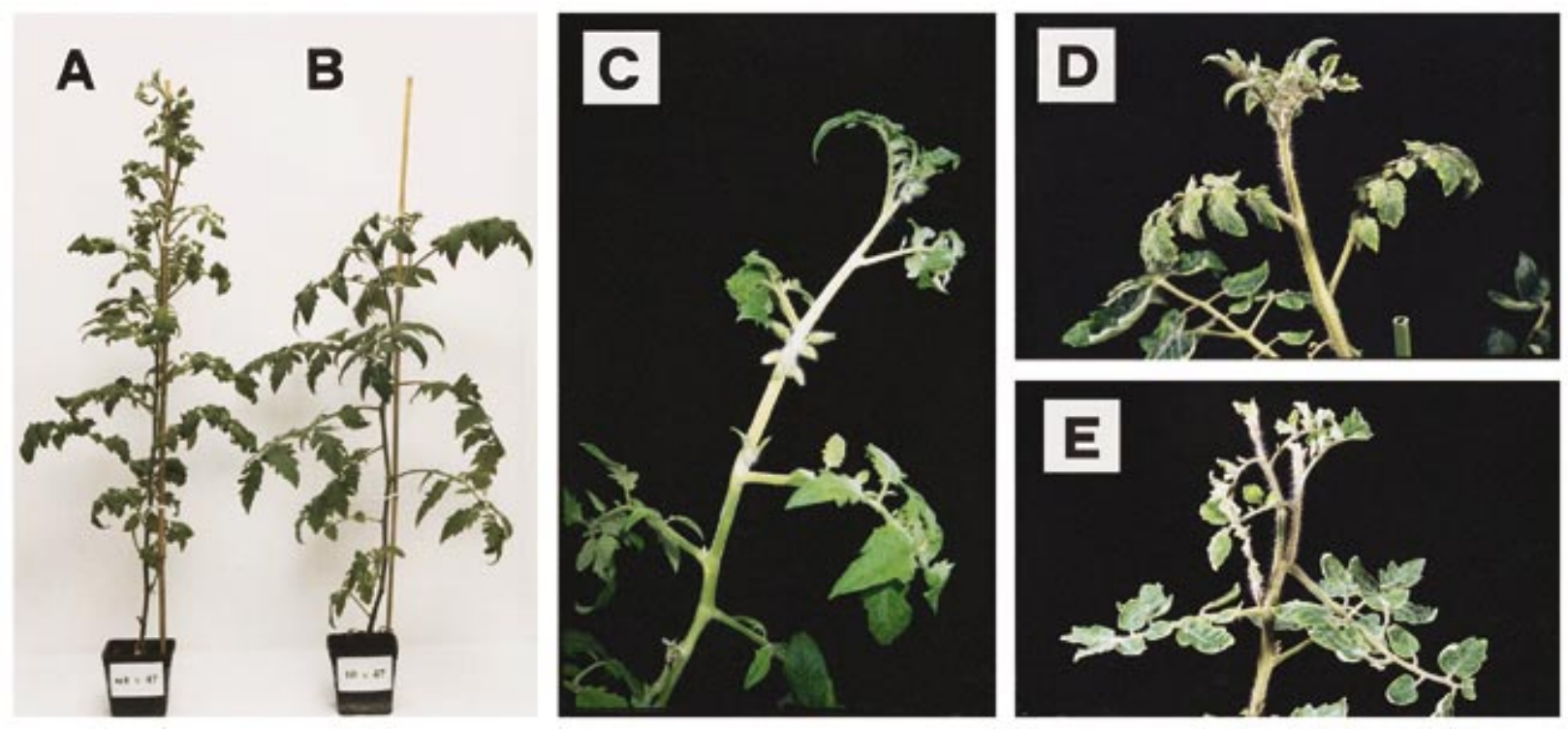

Fig. 4. Unchallenged plants and apical regions of plants challenged with tomato yellow leaf curl virus TYLCV-Sr and tomato leaf curl virus ToLCV-Au. A, BC1 (wild type $[\mathrm{wt}] \times 47$ ) plant, showing curled phenotype. $\mathbf{B}, \mathrm{F}_{1} 10 \times 47$ plant, carrying both sense and antisense genes, showing wild-type phenotype. C, $F_{1} 10 \times 47$ plant \#106 (see Table 3), resistant to TYLCV-Sr. D, Nontransformed plant, infected by TYLCV-Sr. E, F $_{1} 10 \times 47$ plant \#107 (see Table 3), infected by ToLCV-Au. 
$47 \mathrm{~F}_{1}$ plants were grown in soil and analyzed at the molecular level before agroinoculation. Most of the progeny were phenotypically indistinguishable from wild type, while some resembled BC1 progeny. A PCR assay designed to detect the presence of the $C l$ gene in either sense or antisense orientation showed that, except for one segregant (Table 2, plant \#46), all the plants that were phenotypically indistinguishable from the wild type contained the antisense gene, either alone or in combination with the sense gene (Fig. 4B), while the plants with the altered phenotype contained only the sense gene. Segregation of the sense and antisense loci was analyzed in $9 \mathrm{~F}_{1}$ plants by Southern blotting. Total DNA was restricted with HindIII and hybridized with an E35S-specific probe. Line 10 showed two hybridizing fragments of different size easily distinguishable from those deriving from $\mathrm{R}_{0}$ sense line 47 (Fig. 2, lane 3). Southern data from $4 \mathrm{~F}_{1}$ plants (plants $\# 31,50,51$, and 52 in Table 2) were chosen to illustrate some of the observed inheritance patterns (Fig. 2, lanes 6 to 9). The sense loci always occurred singly, as in the case of BC1 plants, while the two antisense loci were found either together, or singly, or were absent. Northern and Western analysis of some representative $F_{1}$ plants (plants \#7, 8, 9, 10, and 14 in Table 2) are shown in Fig. 3 (panels A-C). Plants \#7 and 14, harboring both sense and antisense genes, showed reduced accumulation of both sense and antisense $C l$-specific transcripts, compared with plant \#8 (antisense only) and plants \#9 and 10 (sense only). Reduced $C l$ sense and antisense RNA accumulation in plants having both genes was confirmed by analysis of other $F_{1}$ progenies (data not shown). In Western blots of total protein extracts (Fig. 3C and Table 2) T-Rep

Table 2. Analysis of the correlation between high accumulation of truncated Rep protein and tomato yellow leaf curl virus (TYLCV) resistance in $\mathrm{F}_{1} 10 \times 47$ plants

\begin{tabular}{|c|c|c|c|c|c|}
\hline \multirow{2}{*}{$\begin{array}{l}\text { Plant } \\
\text { no. }\end{array}$} & \multicolumn{2}{|c|}{$\begin{array}{c}\text { Presence of } C 1 \\
\text { transgene }\end{array}$} & \multirow{2}{*}{$\begin{array}{l}\text { Protein expression } \\
\text { before inoculation }\end{array}$} & \multicolumn{2}{|c|}{$\begin{array}{c}\text { Resistance to } \\
\text { TYLCV-Sr (wpi) }^{\text {a }}\end{array}$} \\
\hline & Sense & Antisense & & 4 to 5 & 9 to 10 \\
\hline 7 & + & + & $+/-^{b}$ & $\mathrm{~S}^{\mathrm{c}}$ & $d^{d}$ \\
\hline 8 & - & + & - & $\mathrm{S}$ & $\ldots$ \\
\hline 9 & + & - & + & $\mathrm{R}^{\mathrm{e}}$ & $\mathrm{R}$ \\
\hline 10 & + & - & + & $\mathrm{R}$ & $\mathrm{R}$ \\
\hline 11 & + & + & - & S & $\ldots$ \\
\hline 12 & + & + & - & S & $\ldots$ \\
\hline 13 & + & + & - & S & $\ldots$ \\
\hline 14 & + & + & $+1-$ & $\mathrm{S}$ & $\ldots$ \\
\hline 15 & + & + & - & S & $\ldots$ \\
\hline 16 & + & + & - & $\mathrm{S}$ & $\ldots$ \\
\hline 29 & + & - & + & $\mathrm{R}$ & $\mathrm{R}$ \\
\hline 30 & + & + & - & S & $\ldots$ \\
\hline 31 & + & + & - & S & $\ldots$ \\
\hline 46 & - & - & - & $\mathrm{S}$ & $\ldots$ \\
\hline 48 & + & + & - & $\mathrm{S}$ & $\ldots$ \\
\hline 49 & + & - & + & $\mathrm{R}$ & $\mathrm{S}$ \\
\hline 50 & + & + & $+/-$ & $\mathrm{S}$ & $\ldots$ \\
\hline 51 & + & + & - & $\mathrm{S}$ & $\ldots$ \\
\hline 52 & + & + & - & S & $\ldots$ \\
\hline 53 & + & + & - & S & $\ldots$ \\
\hline $\mathrm{wt}^{\mathrm{f}}$ & - & - & - & $\mathrm{S}$ & $\ldots$ \\
\hline
\end{tabular}

${ }^{\mathrm{a}}$ Weeks post inoculation.

${ }^{\mathrm{b}}$ Hardly detectable.

${ }^{c}$ Susceptible.

${ }^{\mathrm{d}}$ Not determined.

${ }^{\mathrm{e}}$ Resistant.

${ }^{\mathrm{f}}$ Wild type. protein was easily detected in plants carrying the sense gene alone, while in those with both sense and antisense genes it was undetectable or hardly detectable (plants \#7, 14, and 50), regardless of which sense and antisense loci were present.

The $20 \mathrm{~F}_{1}$ plants analyzed at the molecular level were agroinoculated with TYLCV-Sr, observed for symptom development, and assayed for the presence of viral DNA by the leaf squash hybridization assay. At 4 to $5 \mathrm{wpi}$, plants harboring only the sense $C l$ gene (\#9, 10, 29, and 49) contained no detectable TYLCV-Sr DNA, while all plants harboring either antisense alone or both antisense and sense genes were susceptible to TYLCV-Sr (Table 2). Plants scored as resistant were further assayed at 9 to $10 \mathrm{wpi}$. At that time, plant \#49 was found to be infected.

\section{ToLCV-Au overcomes T-Rep-mediated resistance.}

Our results thus showed a correlation between high expression of the sense $C l$ gene, resistance to TYLCV-Sr, and altered phenotype. To analyze whether accumulation of T-Rep induced a nonspecific virus resistance by altering physiological conditions, we challenged the transgenic plants with another geminivirus, ToLCV-Au (Dry et al. 1993). Eighteen 10 $\times 47 \mathrm{~F}_{1}$ plants were analyzed at the molecular level, divided into two groups, and agroinoculated with either TYLCV-Sr or ToLCV-Au (Table 3). Each group consisted of plants carrying only the sense gene, as well as others in which both genes were present. At $4 \mathrm{wpi}$, in the group of plants inoculated with TYLCV-Sr only those accumulating high levels of T-Rep were resistant to viral infection, as observed in previous experiments (Fig. 4C and D). In the group inoculated with ToLCV$\mathrm{Au}$ all plants, including those accumulating high levels of $\mathrm{T}$ Rep, were susceptible to ToLCV-Au (Table 3 and Fig. 4E).

Table 3. Analysis of $F_{1} 10 \times 47$ plants challenged by tomato leaf curl virus ToLCV-Au and tomato yellow leaf curl virus TYLCV-Sr

\begin{tabular}{|c|c|c|c|c|c|c|}
\hline \multirow[b]{2}{*}{ Virus } & \multirow{2}{*}{$\begin{array}{c}\text { Plant } \\
\text { no. }\end{array}$} & \multicolumn{2}{|c|}{$\begin{array}{c}\text { Presence of } \mathrm{Cl} \\
\text { transgene }\end{array}$} & \multirow{2}{*}{$\begin{array}{l}\text { Protein expression } \\
\text { before inoculation }\end{array}$} & \multicolumn{2}{|c|}{$\begin{array}{c}\text { Resist. } \\
\text { wpi }^{\mathbf{a}}\end{array}$} \\
\hline & & Sense & Antisense & & 4 & 10 \\
\hline \multirow[t]{10}{*}{ ToLCV-Au } & 101 & + & + & - & $S^{b}$ & $\ldots{ }^{c}$ \\
\hline & 103 & + & + & - & S & $\ldots$ \\
\hline & 105 & + & + & - & S & $\ldots$ \\
\hline & 107 & + & - & + & S & $\mathrm{S}$ \\
\hline & 110 & + & - & + & $\mathrm{S}$ & $\mathrm{S}$ \\
\hline & 111 & + & + & - & $\mathrm{S}$ & $\ldots$ \\
\hline & 113 & + & - & + & $\mathrm{S}$ & $\mathrm{S}$ \\
\hline & 114 & + & + & - & S & $\ldots$ \\
\hline & 116 & + & + & - & S & $\ldots$ \\
\hline & $w t^{d}$ & - & - & - & $\mathrm{S}$ & $\mathrm{S}$ \\
\hline \multirow[t]{10}{*}{ TYLCV } & 102 & + & + & - & $\mathrm{S}$ & \\
\hline & 104 & + & + & - & S & \\
\hline & 106 & + & - & + & $\mathrm{R}^{\mathrm{e}}$ & $\mathrm{R}$ \\
\hline & 108 & + & - & + & $\mathrm{R}$ & $\mathrm{R}$ \\
\hline & 109 & + & + & - & $\mathrm{S}$ & $\ldots$ \\
\hline & 112 & + & + & - & $\mathrm{S}$ & $\ldots$ \\
\hline & 115 & + & + & - & $\mathrm{S}$ & $\ldots$ \\
\hline & 117 & + & - & + & $\mathrm{R}$ & $\mathrm{R}$ \\
\hline & 118 & + & - & + & $\mathrm{R}$ & $\mathrm{S}$ \\
\hline & wt & $\ldots$ & $\ldots$ & $\ldots$ & $\mathrm{S}$ & $\ldots$ \\
\hline
\end{tabular}

${ }^{a}$ Resistance at 4 or 10 weeks post inoculation (wpi).

b Susceptible.

c Not determined.

d Wild type.

e Resistant. 


\section{DISCUSSION}

We have recently shown that it is possible to obtain resistance to TYLCV-Sr by expressing a truncated $C l$ gene in transgenic $N$. benthamiana plants (Noris et al. 1996). However, the resistance was present only in a few plants and was not inherited and expressed in a Mendelian manner. Furthermore, not all plants with detectable transgenic Rep at the time of infection were resistant, suggesting that a threshold level of expression may be necessary to confer resistance. Resistance was eventually overcome with time in most plants. We also showed that efficient inhibition of TYLCV-Sr DNA replication can be achieved by expressing the T-Rep protein in tobacco protoplasts, although expression of the mRNA only was not sufficient.

In the present work we obtained tomato plants transformed with the same construct used in N. benthamiana. Due to stable expression of the transgene in two different hybrid progenies, it was possible to better study the correlation between transgene expression and resistance, to extend our understanding of the specificity of resistance, and to test how plants perform when challenged with TYLCV-Sr via the whitefly vector.

Segregation and Southern analysis of wt $\times 47$ hybrid progeny (BC1) indicated that two independent integration loci are present in plant 47 . The absence of a single segregant wildtype plant among the $55 \mathrm{BC} 1$ plants analyzed by PCR and the presence of only one single $C 1$ locus (A or B) in all the 27 BC1 plants analyzed by Southern blots suggest that the loci are at similar positions on homologous chromosomes. This hypothesis is also in accord with the segregation pattern of 10 $\times 47$ hybrids (Tables 2 and 3) and with the absence of plants with wild-type phenotype among $300 \mathrm{R}_{1}$ seedlings of plant 47 . Each locus, in heterozygous condition, conferred TYLCV-Sr resistance (Table 1) and induced the altered plant phenotype, indicating that the two phenomena result from transgene expression rather than from a particular T-DNA integration in the host genome.

The "curled" phenotype, always associated with T-Rep accumulation, can be partially explained by a proposed influence of geminivirus Rep proteins on plant host factors involved in cell cycle regulation (Nagar et al. 1995; Xie et al. 1995; Collin et al. 1996). However, transgenic $N$. benthamiana plants expressing three times more wild-type Rep protein of TGMV than in TGMV-infected tissue and accumulating, in the terminally differentiated cells, the plant homologue of the animal proliferating cell nuclear antigen, were phenotypically normal and fertile (Hanley-Bowdoin et al. 1990; Nagar et al. 1995). We cannot estimate how much T-Rep accumulated in our transgenics compared with the wild-type Rep in infected plants, because we were unable to detect the latter. The observation that plants with a reduced level of transgene expression show normal phenotype also points to a role of T-Rep in the altered one. A toxic effect of T-Rep was already suspected in $N$. benthamiana, where some $\mathrm{R}_{1}$ progeny did not germinate and others grew poorly (Noris et al. 1996). The impossibility of growing $R_{1}$ progeny of tomato plant 47 may also have resulted from overexpression of the transgenic protein. The $\mathrm{R}_{0}$ plant 47 accumulated less $\mathrm{T}$-Rep than its $\mathrm{BC} 1$ progeny, and showed only a general paler color when compared with nontransformed plants. It is possible that the level of transgene expression in this plant, which carries both loci, is lower than in $\mathrm{BC} 1$ plants because of a cosuppression event.
The truncated $C 1$ gene, beside its capacity to encode T-Rep, contains in a different frame the small ORF $C 4$. We are not aware of any report showing or suggesting that $C 4$ may have toxic effects when expressed in plants; however, we cannot exclude the possibility that the altered physiological state we observe may result from $C 4$ expression. In this regard it should be noted that ORF C4 mutants of TYLCV (Jupin et al. 1994), ToLCV (Rigden et al. 1994), and BCTV (Stanley and Latham 1992) elicited attenuated symptoms on some Solanaceae spp., suggesting a possible role of $C 4$ in pathogenicity.

It is now generally assumed that pathogen-derived resistance obtained by expressing coding portions of the viral genome can be either RNA-mediated when the transgene is transcribed at high levels but its mRNA steady-state level is low, or protein-mediated when high steady-state levels of transgene mRNA and protein are detected (for a review see Lomonossoff 1995; Baulcombe 1996). Although all the cases of RNA-mediated resistance so far described concern RNA viruses, we cannot rule out that such a mechanism, as recently proposed by Hong and Stanley (1996) in the case of ACMV, could be effective against DNA viruses. However, in our case, the antisense genetic approach demonstrated that high steadystate levels of transgene expression are required to confer TYLCV-Sr resistance. $F_{1}$ plants from the cross $10 \times 47$ and containing both the sense and antisense transgenes accumulated much lower amounts of $C 1$ sense-specific RNA and TRep and were susceptible to TYLCV-Sr infection, while those containing only the sense gene accumulated high amounts of T-Rep and were resistant.

As mentioned above, the construct used in our work also contains ORF C4, which has been suggested to be involved in systemic movement of the virus in tomato plants (Jupin et al. 1994). However, no variation in efficiency of viral DNA replication between the $C 4$ mutant used and the wild-type TYLCV-Sr was observed (Jupin et al. 1994). Our data with a leaf disk infection assay showed that in $\mathrm{BC} 1$ plants the level of viral DNA was significantly reduced, compared with nontransformed control plants. Moreover, efficient inhibition of TYLCV-Sr DNA replication in protoplasts was only achieved by utilizing a truncated $C 1$ gene construct encoding the T-Rep protein (Noris et al. 1996), thus indicating that neither the truncated mRNA per se nor the $\mathrm{C} 4$ protein, if expressed, were involved in the inhibition of TYLCV-Sr replication. Although transient expression experiments do not always accurately mimic the resistance mechanism operating in transgenic plants (Lomonossoff 1995; Baulcombe 1996), the requirement of high T-Rep accumulation in $\mathrm{F}_{1} 10 \times 47$ resistant plants correlates well with the results obtained with protoplasts, suggesting that T-Rep is the molecule responsible for the observed resistance.

How does T-Rep confer resistance? The complete susceptibility of TYLCV-Sr resistant plants to ToLCV-Au indicates that the resistance was not due to an aspecific toxic effect of highly expressed T-Rep. The proposed roles of geminivirus Rep suggest two possible explanations of the observed resistance. First, T-Rep could act as a dominant-negative mutant (Herskowitz 1987) by competing with wild-type Rep for binding to viral DNA and thus impairing its replication capacity or, if Rep acts as multimer, as speculated by HeyraudNitschke et al. (1995), it could interact with the wild-type Rep to generate a dysfunctional product. Second, T-Rep could re- 
press transcription of the viral $C l$ gene through interaction with its upstream recognition sequence (Fontes et al. 1992; Sunter et al. 1993; Eagle et al. 1994; Hong and Stanley 1995), thus abolishing or limiting wild-type Rep accumulation.

Both models can account for the requirement of a threshold level of T-Rep to confer TYLCV-Sr resistance. Although we do not know the amount of T-Rep in the transgenic plant available for interaction with viral DNA and/or wild-type Rep, the fact that we have never been able to detect the wild-type Rep in TYLCV-Sr-infected tissue suggests that an excess of T-Rep over the wild-type version is required to confer resistance.

Interference with viral infection by defective viral replication-associated proteins was shown for the coliphage Q beta (Inokuchi and Hirashima 1987) and the adeno-associated virus (Chejanovsky and Carter 1990). In both cases the dysfunctional proteins seem to act as dominant negative mutants (Inokuchi and Hirashima 1990; Owens and Carter 1992). Although virus-resistant transgenic plants have been obtained expressing viral genes encoding wild-type or mutated replication-associated proteins, evidence for a direct correlation between high steady-state levels of transgene expression and resistance is still lacking (Baulcombe 1996; Prins and Goldbach 1996), with the exception of tobacco plants transformed with modified $P 2$ genes of alfalfa mosaic virus (AlMV) (Brederode et al. 1995). In their work, Brederode et al. showed that AlMV resistant lines accumulated high amounts of transgene mRNA, but mutated proteins were not detected and the correlation between resistance and high accumulation of the transcripts in the lines segregating the resistance character was not investigated.

We have shown that a transgene stably expressing in tomato a truncated Rep protein confers resistance to TYLCV-Sr. The evidence that some initially resistant plants later became infected suggests active competition between T-Rep and incoming virus. The result of such competition could also be influenced by the type and dose of inoculum. In experiments on resistance to TYLCV-Is in tomato lines, Michelson et al. (1994) showed that use of the whitefly vector can dramatically influence resistance assays: at 8 wpi with a low level of inoculum ( 3 whiteflies per plant) only 3 out of the 10 tomato plants contained detectable viral DNA, while $100 \%$ infection was already achieved at 4 wpi with Agrobacterium at low inoculum concentration. Our experiments, too, showed that different levels of resistance resulted from two inoculation techniques: about 4 months after inoculation, approximately $65 \%$ transgenic plants were resistant when Agrobacterium was used (see Table 1), while no plant became infected if challenged with $B$. tabaci (20 whiteflies per plant).

Although in our $C l$ highly expressing plants resistance was correlated with an altered phenotype, it may in future be possible to dissociate the two phenomena with genetic constructs expressing different dysfunctional forms of T-Rep protein or expressing the same T-Rep in a different genetic plant background.

\section{MATERIALS AND METHODS}

\section{Plant transformation.}

Transformation of tomato cotyledons (Lycopersicon esculentum cv. Moneymaker) with Agrobacterium tumefaciens C58 pGV2260 (Deblaere et al. 1985) harboring the plasmid pTom 102 (Noris et al. 1996) was performed according to van Roekel et al. (1993) with minor modifications. After 5 weeks on selective medium, explants showing primordia were transferred to new plates containing the same medium, but with reduced concentrations of zeatin riboside $(0.5 \mu \mathrm{g} / \mathrm{ml})$ and kanamycin $(\mathrm{km})$ $(50 \mu \mathrm{g} / \mathrm{ml})$. Eight weeks later, regenerated plants were transferred to rooting medium (Novak and Maskova 1979) containing indole-3-butyric acid $(0.1 \mu \mathrm{g} / \mathrm{ml})$. The ploidy level of the $\mathrm{R}_{0}$ plants 47 and 10 was measured by flow cytometry on nuclear DNA as described by Dolezel et al. (1989).

\section{Molecular analysis of transgenic plants.}

The presence of $C l$ and $n p t I I$ transgenes was analyzed by PCR from leaf tissue samples as described by Klimyuk et al. (1993). Amplifications were performed with primer p111 (5' GCC AAG ATC AGG TCG TTT TAG TAT C 3'), which covers the $5^{\prime}$ end of ORF $C 1$ and pUC/M13 reverse sequencing primer (-48) for the $C 1$ sense transgene or p111 and pUC/M13 sequencing primers (-47) for the $C l$ antisense transgene; the primers used for the nptII transgene were as described by Dong and McHughen (1993). Reactions were run for $35 \mathrm{cy}-$ cles of $94^{\circ} \mathrm{C}$ for $45 \mathrm{~s}, 60^{\circ} \mathrm{C}$ for $1 \mathrm{~min}$, and $72^{\circ} \mathrm{C}$ for $1 \mathrm{~min}$ with a hot-start procedure. Transgene copy number was determined by Southern blot analysis. Two micrograms of genomic DNA, extracted essentially as described by Dellaporta et al. (1983), was digested with KpnI, BamHI, or HindIII, fractionated by agarose gel electrophoresis in TAE (40 mM Tris-acetate, $\mathrm{pH}$ 8.3 , and 1 mM EDTA) buffer and transferred to nylon membranes. Filters were hybridized with either C1- (Noris et al. 1996) or E35S-specific digoxigenin-labeled RNA probes, obtained with the DIG RNA labeling kit (Boehringer Mannheim, Mannheim, Germany). The hybridization, washing, and detection conditions were according to manufacturer's recommendations. The plasmid containing the E35S promoter downstream of the $\mathrm{T} 7$ promoter was obtained by subcloning the KpnI-BamHI fragment of pTom102 in pGEM7Z(+) (Promega, Madison, WI).

Total RNA was isolated from leaves according to Ilardi et al. (1995). Polyadenylated, enriched RNA fraction was obtained from total RNA by one cycle of affinity chromatography on oligo(dT)-cellulose with the mRNA Purification Kit (Pharmacia Biotech, Uppsala, Sweden). One microgram of poly $(A)^{+}$RNA ( $\mathrm{R}_{0}$ plants) or $20 \mu \mathrm{g}$ of total RNA ( $\mathrm{F}_{1}$ progeny) was electrophoresed in a formaldehyde-permeated agarose gel (Sambrook et al. 1989) or in agarose gels following denaturation with glyoxal and formamide (Mc Master and Carmichael 1977), respectively, and transferred to nylon membranes. Membranes were hybridized with sense or antisense $C 1$ digoxigenin-labeled RNA probes as described by Noris et al. (1996). Total proteins extraction from leaf tissue and detection of the transgenic Rep protein by Western blot analysis was performed as described by Noris et al. (1996), loading about $500 \mathrm{ng}$ of total proteins in each lane.

\section{Virus resistance assays.}

Plants were inoculated either by agroinoculation or, in a few cases, with the whitefly vector. For agroinoculations, the $A$. tumefaciens strain LBA4404/pBin19/TYLCV-Sr1.8 (KheyrPour et al. 1991) containing a redundant copy of TYLCV-Sr DNA in pBin19 was used. Plants, sown in soil and grown in glasshouse at $25^{\circ} \mathrm{C}$ with a photoperiod of $14 \mathrm{~h}$, were inoculated at the 6- to 8-leaf stage by removing the apex and in- 
jecting the Agrobacterium suspension $\left(\mathrm{OD}_{600}>10\right)$ into the wound and leaf axils. The excised apices were used for molecular analysis. Nontransgenic control plants were included in each experiment. For infections with tomato leaf curl geminivirus the infectious clone pTLCBIN1 (ToLCV-Au; Dry et al. 1993) was used.

For inoculation with the vector, Bemisia tabaci whiteflies were confined on TYLCV-Sr-infected tomato plants for a 48$\mathrm{h}$ acquisition access period, then transferred to the $\mathrm{BC} 1$ (cross wt $\times 47)$ transgenic tomatoes (20 insects per plant), individually caged. After 5 days of inoculation access, insects were killed with insecticide and plants were maintained in the glasshouse. Nontransformed tomato plants were included as susceptible controls.

Plants were observed for symptom development in an insect-proof glasshouse and analyzed for the presence of viral DNA. A small piece of the youngest expanding leaf near the apex was squashed on positively charged nylon membrane (Boehringer). Membranes were hybridized with a ${ }^{32} \mathrm{P}$-labeled probe specific for the TYLCV-Sr coat protein gene, or, for plants inoculated with ToLCV-Au, with a ToLCV-Au-specific probe.

\section{Leaf disk assays.}

Leaf disks were prepared from $\mathrm{BC} 1$ and nontransformed plants by the same procedure as for cotyledon transformation (van Roekel et al. 1993), and agroinoculated with A. tumefaciens EHA105 (Hood et al. 1993) harboring the pBin19/ TYLCV-Sr1.8 TYLCV-Sr infectious clone (Kheyr-Pour et al. 1991), essentially by following the procedure described by Czosnek et al. (1993). Six days after transference to selective medium, total DNA was extracted (Dellaporta et al. 1983) from batches of 4 to 7 disks, and TYLCV-Sr DNA replication was analyzed by Southern blotting with a $C l$ antisense digoxigenin-labeled RNA probe.

\section{ACKNOWLEDGMENTS}

We thank S. Lucretti for flow cytometric analysis; D. Chiaretti, M. Vecchiati, and F. Veratti for excellent technical assistance; D. Marian for whitefly work; G. P. Gaviani and L. Grisorio for the photographs; and R. G. Milne for critical reading of the manuscript. We are also grateful to A. Rezaian and I. Dry (CSIRO, Adelaide, Australia) for kindly providing pTLCBIN1. This work was supported by the Italian Ministry for Agriculture and Forestry (MiRAAF) and by the National Research Council of Italy, Special Project RAISA, Subproject 2.

\section{LITERATURE CITED}

Baulcombe, D. C. 1996. Mechanisms of pathogen-derived resistance to viruses in transgenic plants. Plant Cell 8:1833-1844.

Brederode, F. T., Taschner, P. E. M., Posthumus, E., and Bol, J. F. 1995. Replicase-mediated resistance to alfalfa mosaic virus. Virology 207: 467-474.

Briddon, R. W., and Markham, P. G. 1995. Family Geminiviridae. Pages 158-165 in: Virus Taxonomy. Classification and Nomenclature of Viruses. Sixth Report of the International Committee on Taxonomy of Viruses. F. A. Murphy, C. M. Fauquet, D. H. L. Bishop, S. A. Ghabrial, A. W. Jarvis, G. P. Martelli, M. A. Mayo, and M. D. Summers, eds. Springer-Verlag, Vienna.

Chejanovsky, N., and Carter, B. J. 1990. Mutation of a consensus purine nucleotide binding site in the adeno-associated virus rep gene generates a dominant negative phenotype for DNA replication. J. Virol. 64:1764-1770.

Choi, I. R., and Stenger, D. C. 1995. Strain-specific determinants of beet curly top geminivirus DNA replication. Virology 206:904-912.

Collin, S., Fernandez-Lobato, M., Gooding, P. S., Mullineaux, P. M., and Fenoll, C. 1996. The two nonstructural proteins from wheat dwarf virus involved in viral gene expression and replication are retinoblastoma-binding proteins. Virology 219:324-329.

Czosnek, H., Kheyr-Pour, A., Gronenborn, B., Remetz, E., Zeidan, M., Altman, A., Rabinowitch, H. D., Vidavsky, S., Kedar, N., Gafni, Y., and Zamir, D. 1993. Replication of tomato yellow leaf curl virus (TYLCV) DNA in agroinoculated leaf disks from selected tomato genotypes. Plant Mol. Biol. 22:995-1005.

Czosnek, H., Navot, N., and Laterrot, H. 1990. Geographical distribution of Tomato yellow leaf curl virus. A first survey using a specific DNA probe. Phytopathol. Mediterr. 29:1-6.

Day, A. G., Bejarano, E. R., Buck, K. W., Burrell, M., and Lichtenstein, C. P. 1991. Expression of an antisense viral gene in transgenic tobacco confers resistance to the DNA virus tomato golden mosaic virus. Proc. Natl. Acad. Sci. USA 88:6721-6725.

Deblaere, R., Bytebier, B., De Greve, H., Deboeck, F., Schell, J., van Montagu, M., and Leemans, J. 1985. Efficient octopine Ti plasmidderived vectors for Agrobacterium-mediated gene transfer to plants. Nucleic Acids Res. 13:4777-4788.

Dellaporta, S. L., Wood, J., and Hicks, J. B. 1983. A plant DNA minipreparation: version II. Plant Mol. Biol. Rep. 4:19-21.

Desbiez, C., David, C., Mettouchi, A., Laufs, J., and Gronenborn, B. 1995. Rep protein of tomato yellow leaf curl geminivirus has an ATPase activity required for viral DNA replication. Proc. Natl. Acad. Sci. USA 92:5640-5644.

Dolezel, J., Binarova, P., and Lucretti, S. 1989. Analysis of nuclear DNA content in plant cells by flow cytometry. Biol. Plant. 31:113-120.

Dong, J. Z., and McHughen, A. 1993. An improved procedure for production of transgenic flax plants using Agrobacterium tumefaciens. Plant Sci. 88:61-71.

Dry, I. B., Ridgen, J. E., Krake, L. R., Mullineaux, P. M., and Rezaian, M. A. 1993. Nucleotide sequence and genome organization of tomato leaf curl geminivirus. J. Gen. Virol. 74:147-151.

Eagle, P. A., Orozco, B. M., and Hanley-Bowdoin, L. 1994. A DNA sequence required for geminivirus replication also mediates transcriptional regulation. Plant Cell 6:1157-1170.

Elmer, J. S., Brand, L., Sunter, G., Gardiner, W. E., Bisaro, D. M., and Rogers, S. G. 1988. Genetic analysis of the tomato golden mosaic virus II. The product of the $A L 1$ coding sequence is required for replication. Nucleic Acids Res. 16:7034-7060.

Etessami, P., Saunders, K., Watts, J., and Stanley, J. 1991. Mutational analysis of complementary-sense genes of African cassava mosaic virus DNA A. J. Gen. Virol. 72:1005-1012.

Fontes, E. P. B., Eagle, P. A., Sipe, P. S., Luckow, V. A., and HanleyBowdoin, L. 1994. Interaction between a geminivirus replication protein and origin DNA is essential for viral replication. J. Biol. Chem. 269:8459-8465.

Fontes, E. P. B., Luckow, V. A., and Hanley-Bowdoin, L. 1992. A geminivirus replication protein is a sequence-specific DNA binding protein. Plant Cell 4:597-608.

Frischmuth, T., and Stanley, J. 1994. Beet curly top virus symptom amelioration in Nicotiana benthamiana transformed with a naturally occurring viral subgenomic DNA. Virology 200:826-830.

Hanley-Bowdoin, L., Elmer, J. S., and Rogers, S. G. 1990. Expression of functional replication protein from tomato golden mosaic virus in transgenic tobacco plants. Proc. Natl. Acad. Sci. USA 87:1446-1450.

Hanson, S. F., Hoogstraten, R. A., Ahlquist, P., Gilbertson R. L., Russell, D. R., and Maxwell, D. P. 1995. Mutational analysis of a putative NTP-binding domain in the replication-associated protein (AC1) of bean golden mosaic geminivirus. Virology 211:1-9.

Herskowitz, I. 1987. Functional inactivation of genes by dominant negative mutations. Nature 329:219-222.

Heyraud-Nitschke, F., Schumacher, S., Laufs, J., Schaefer, S., Schell, J., and Gronenborn, B. 1995. Determination of the origin cleavage and joining domain of geminivirus Rep proteins. Nucleic Acids Res. 23: 910-916.

Hong, Y., and Stanley, J. 1995. Regulation of African cassava mosaic virus complementary-sense gene expression by $\mathrm{N}$-terminal sequences of the replication-associated protein AC1. J. Gen. Virol. 76:2415-2422.

Hong, Y., and Stanley, J. 1996. Virus resistance in Nicotiana benthamiana conferred by African cassava mosaic virus replication-associated protein (AC1) transgene. Mol. Plant-Microbe Interact. 9:219-225. 
Hood, E. E., Gelvin, S. B., Melchers, L. S., and Hoekema, A. 1993. New Agrobacterium helper plasmids for gene transfer to plants. Transgenic Res. 2:208-218.

Ilardi, V., Maze, M., Loretta, S., Tomassoli, L., and Barba, M. 1995. Biomolecular and serological methods to identify strains of cucumber mosaic cucumovirus on tomato. Eur. Mediterr. Plant Prot. Org. 25: 321-327.

Inokuchi, Y., and Hirashima, A. 1987. Interference with viral infection by defective RNA replicase. J. Virol. 61:3946-3949.

Inokuchi, Y., and Hirashima, A. 1990. Interference with viral infection by RNA replicase deleted at the carboxy-terminal region. J. Biochem. 108:53-58.

Jupin, I., De Kouchkovsky, F., Jouanneau, F., and Gronenborn, B. 1994. Movement of tomato yellow leaf curl virus geminivirus (TYLCV): involvement of the protein encoded by ORF C4. Virology 204:82-90.

Jupin, I., Hericourt, F., Benz, B., and Gronenborn, B. 1995. DNA replication specificity of TYLCV geminivirus is mediated by the aminoterminal 116 amino acids of the Rep protein. FEBS Letters 362:116-120.

Kheyr-Pour, A., Bendahmane, M., Matzeit, V., Accotto, G. P., Crespi, S., and Gronenborn, B. 1991. Tomato yellow leaf curl virus from Sardinia is a whitefly-transmitted monopartite geminivirus. Nucleic Acids Res. 19:6763-6769.

Klimyuk, V. I., Carroll, B. J., Thomas, C. M., and Jones, J. D. G. 1993. Alkali treatment for rapid preparation of plant material for reliable PCR analysis. Plant J. 3:493-494.

Kunik, T., Salomon, R., Zamir, D., Navot, N., Zeidan, M., Michelson, I., Gafni, Y., and Czosnek, H. 1994. Transgenic tomato plants expressing the tomato yellow leaf curl virus capsid protein are resistant to the virus. Bio/Technology 12:500-504.

Laufs, J., Traut, W., Heyraud, F., Matzeit, V., Rogers, S. G., Schell, J., and Gronenborn, B. 1995. In vitro cleavage and joining at the viral origin of replication by the replication initiator protein of tomato yellow leaf curl virus. Proc. Natl. Acad. Sci. USA 92:3879-3883.

Lazarowitz, S. G., Wu, L. C., Rogers, S. G., and Elmer, J. S. 1992. Sequence-specific interaction with the viral AL1 protein identifies a geminivirus DNA replication origin. Plant Cell 4:799-809.

Lomonossoff, G. P. 1995. Pathogen-derived resistance to plant viruses. Annu. Rev. Phytopathol. 33:323-343.

Mc Master, G. K., and Carmichael, G. G. 1977. Analysis of single- and double-stranded nucleic acids on polyacrylamide and agarose gels by using glyoxal and acridine orange. Proc. Natl. Acad. Sci. USA 74: 4835-4838.

Michelson, I., Zamir D., and Czosnek, H. 1994. Accumulation and translocation of tomato yellow leaf curl virus (TYLCV) in a Lycopersicon esculentum breeding line containing the $L$. chilense TYLCV tolerance gene Ty-1. Phytopathology 84:928-933.

Nagar, S., Pedersen, T. J., Carrick, K. M., Hanley-Bowdoin, L., and Robertson, D. 1995. A geminivirus induces expression of a host DNA synthesis protein in terminally differentiated plant cells. Plant Cell 7: 705-719.

Navot, N., Pichersky, E., Zeidan, M., Zamir, D., and Czosnek, H. 1991. Tomato yellow leaf curl virus: A whitefly-transmitted geminivirus with a single genomic component. Virology 185:151-161.

Noris, E., Accotto, G. P., Tavazza, R., Brunetti, A., Crespi, S., and Tavazza, M. 1996. Resistance to tomato yellow leaf curl geminivirus in Nicotiana benthamiana plants transformed with a truncated viral C1 gene. Virology 224:130-138.

Novak, F. J., and Maskova, I. 1979. Apical shoot tip culture of tomato. Sci. Hortic. 10:337-344.

Owens, R. A., and Carter, B. J. 1992. In vitro resolution of adenoassociated virus DNA hairpin termini by wild-type Rep protein is inhibited by a dominant-negative mutant of rep. J. Virol. 66:1236-1240.

Prins, M., and Goldbach, R. 1996. RNA-mediated virus resistance in transgenic plants. Arch. Virol. 141:2259-2276.

Rigden, J. E., Krake, R. L., Rezaian, M. A., and Dry, I. B. 1994. ORF C4 of tomato leaf curl geminivirus is a determinant of symptom severity. Virology 204:847-850.

Rochester, D. E., DePaulo, J. J., Fauquet, C. M., and Beachy, R. N. 1994. Complete nucleotide sequence of the geminivirus tomato yellow leaf curl virus, Thailand isolate. J. Gen. Virol. 75:477-485.

Sambrook, J., Fritsch, E. F., and Maniatis, T. A. 1989. Molecular Cloning: A Laboratory Manual. 2nd ed. Cold Spring Harbor Laboratory, Cold Spring Harbor, NY.

Sanford, J. C., and Johnston, S. A. 1985. The concept of parasite-derived resistance: Deriving resistance genes from the parasite's own genome. J. Theor. Biol. 113:395-405.

Stanley, J., Frischmuth, T., and Ellwood, S. 1990. Defective viral DNA ameliorates symptoms of geminivirus infection in transgenic plants. Proc. Natl. Acad. Sci. USA 87:6291-6295.

Stanley, J., and Latham, J. R. 1992. A symptom variant of beet curly top geminivirus produced by mutation of open reading frame $C 4$. Virology 190:506-509.

Stenger, D. C. 1994. Strain-specific mobilization and amplification of a transgenic defective-interfering DNA of the geminivirus beet curly top virus. Virology 203:397-402.

Sunter, G., Hartitz, M. D., and Bisaro, D. M. 1993. Tomato golden mosaic virus leftward gene expression: Autoregulation of geminivirus replication protein. Virology 195:275-280.

van Roekel, J. S. C., Damm, B., Melchers, L. S., and Hoekema, A. 1993. Factors influencing transformation frequency of tomato (Lycopersicon esculentum). Plant Cell Rep. 12:644-647.

Xie, Q., Suarez-Lopez, P., and Gutierrez, C. 1995. Identification and analysis of a retinoblastoma binding motif in the replication protein of a plant DNA virus: Requirement for efficient viral DNA replication. EMBO J. 14:4073-4082.

Zakay, Y., Navot, N., Zeidan, M., Kedar, N., Rabinowitch, H., Czosnek, H., and Zamir, D. 1991. Screening Lycopersicon accessions for resistance to tomato yellow leaf curl virus: Presence of viral DNA and symptom development. Plant Dis. 75:279-281.

Zamir, D., Ekstein-Michelson, I., Zakay, Y., Navot, N., Zeidan, M., Sarfatti, M., Eshed, Y., Harel, E., Pleban, T., van-Oss, H., Kedar, N., Rabinowitch, H. D., and Czosnek, H. 1994. Mapping and introgression of a tomato yellow leaf curl virus tolerance gene, TY-1. Theor. Appl. Gen. 88:141-146. 